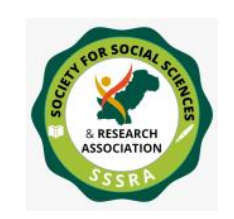

\title{
EDUCATION SECTOR OF PAKISTAN: NEXT VICTIM OF TERRORISM AND EXTREMISM IN A GLOBALIZED ENVIRONMENT
}

Ayaz Khan, Research Scholar, Department of International Relations, University of Karachi. (myworldayaz@gmail.com)

\begin{abstract}
Globalization has affected the education sector of Pakistan differently because of its peculiar and diversed security challenges. An extremely cunning hostile enemy on east who always stages all kind of clandestine operations against Pakistan. On the western border, Afghanistan has always remained a source of instability for Pakistan. US policy failures in Afghanistan and do more demand by Trump administration from Pakistan without acknowledging its sacrifices are a matter of concern. To retain their national interests transition-co forces are using fifth generation asymmetric warfare in this region. Almost all the segments of our society got affected by worst kind of terrorism and extremism in last fifteen years and the current target is our youth and educational institutes. According to the recent National Human Development Report published in May 2018, Pakistan has the largest percentage of youth ever recorded in its history. 64 percent of the total population is below the age of 30 while 29 percent is between the ages of 15 and 29 years. This youth buldge has critical implications for Pakistan because if not groomed and directed in right direction, will create internal implosion. Our enemy precisely identified our centers of gravity and attacking it with numerous means. Be it the Safora Ghot Karachi massacre of forty three innocent unarmed people by Saad Aziz - an Institute of Business Administration (IBA) Karachi graduate or the inhuman killing of human rights activist Sabeen Mahmood by the same man; the IS-indoctrinated and affiliated medical student Noreen Leghari's case or the recent failed attempt on the MQM leader Khawaja Izharul Hassan by a Karachi University graduate, the incessant reality for Pakistani anti-terrorism strategists is that the extremists and terrorists have succeeded in infiltrating modern education institutions and the youth is heing indoctrinated with the toxic ideology of




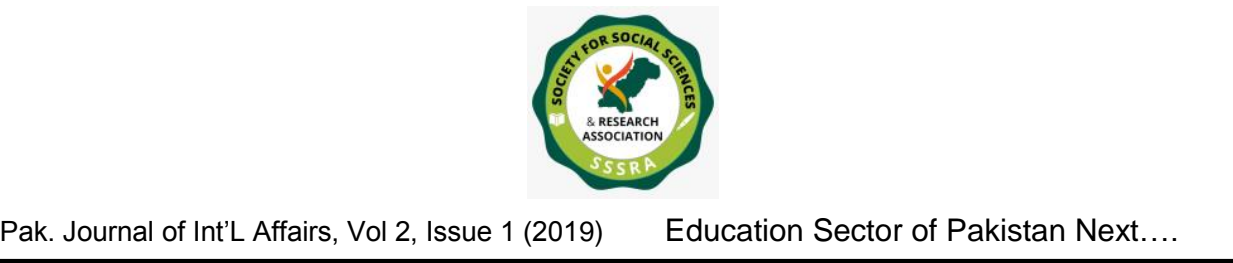

the terrorists. With the defeat of the IS in Syria and Iraq the influx of militants to Pakistan could continue that could further complicate the situation.

The root causes of violent extremism are multifaceted, complex and are derived from structural, as well as micro-level conditions. Similarly, some drivers are proximate in time and space, and operate at the individual level to spread radicalization. Others still are intermediate and long-term, and can create macro-level conditions and forces required for generating and sustaining violent extremism. The first of these root categories can be termed structural push factors. These are state repression, endemic conflict, entrenched corruption, elite impunity, social fragmentation, cultural threat narratives, low literacy levels, poverty, unemployment, identity crisis, personal glory/fame and social networks.

Extremism is a mindset where only a single truth is considered to be valid. It is the antithesis of liberalism. Education is the carrier of liberal values, it is the natural enemy of extremism because it enriches and broadens the mind, enables one to entertain a thought without necessarily accepting it, and creates willingness to live in a society that is democratic, pluralistic, and diverse. But unfortunately, our education system is historically person specific and could not evolve to serve the purpose. Our most precious asset is our youth and we must pay our full attention and focus to save it from extremism. Educational institutes are the backbone of societal development and it would be the worst-case scenario if these might have polluted with extremist ideologies. We want our universities and colleges to be integrated communities where all staff and students are safe and where free and open debate can take place.

In order to eradicate the menace of extremism and terrorism from the education sector, security managers will have to devise an effective monitoring mechanism of religious seminaries targeting colleges and universities. There is dire need to promote ideological security on the part of youngsters to deal with the emerging situation. Pakistan also needs to fight extremism and terrorism on military, political as well as social front. 
Otherwise, the enemy can ruin our youth with its toxic ideology of terror and tyranny.

\section{AIM}

To discuss various aspects relating to extremism faced by Pakistani higher education in a globalized environment with a view to suggest viable response options to combat the threat at national level.

\section{SCHEME OF THE PAPER}

The paper will be covered in the following sequence: -

- $\quad$ Possible Motivating Factors of Extremism

o $\quad$ Key Factors that Lead to Violent Extremism

o $\quad$ Extremism Profiling

o Root causes of Extremism

- $\quad$ Responsible Societal Response to Extremism

o Mindset of Extremism

o A Psychological Warfare

o Terrorists Mindset

- Ideological Security

- $\quad$ The Way Forward

- Conclusion 


\section{DESCRIPTION OF THE STUDY}

\section{THEME}

Globalization and its impact on Society.

Sub- theme

Globalization and its impact on Education.

\section{KEYWORDS AND JEL CLASSIFICATION}

Impact of globalization on education sector of Pakistan, Extremism in education sector of Pakistan.

\section{PURPOSE}

The purpose of this study is to explore the vulnerability of education sector in Pakistan in a globalized environment. The study also attempts to examine the relationship between change in warfare behavior and modern targeting strategies while using terrorism and extremism as tools of hybrid warfare.

\section{DESIGN/METHODOLOGY/APPROACH}

Quantitative research method was used to conduct this study. Data was collected from 22 educational institutions in Pakistan. The data was gathered using survey questionnaire (using5-pointLikertscaleitems), administered both inprint format and online through Google Form. SPSS version 19 was used to analyses the data.

\section{ORIGINALITY/VALUE}

This research will expose the exact reason of extremism in Pakistani youth in its education sector and recommend viable solutions. This is the first study on the vulnerability of Pakistani 


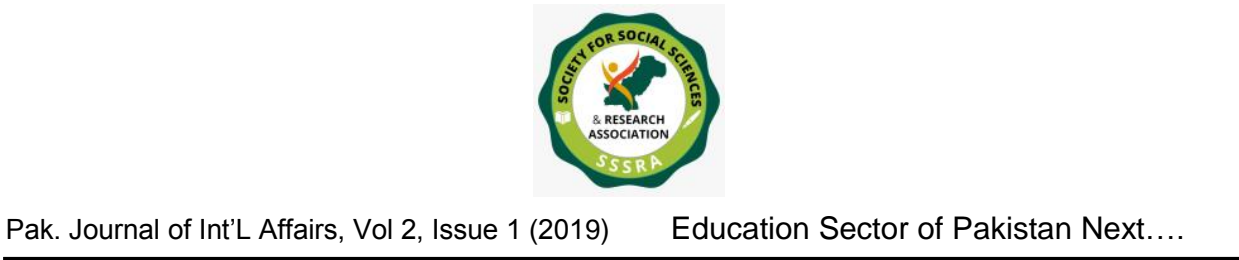

youth in particular time period.

\section{FINDINGS/RESULTS}

Major findings of this study were that there is a strong positive correlation between hybrid warfare and vulnerability of education sector of Pakistan in globalized environment. The study also found Media management, intelligence, Improvisation and technological development are the

essence of development in security domain. Nobody can predict when next war will start and what would be the nature of that war but the time we are passing by we are in constant state of hybrid war, where our enemies are intelligently blending conventional and non-conventional techniques to achieve her policy objectives. Detailed answers of the prepared questionnaire are narrated in subsequent paragraphs.

\section{STUDY / RESEARCH LIMITATIONS}

Study period will cover between 2007-2018 however to find out the root causes older data will also be consulted.

\section{ACADEMIC IMPLICATIONS}

This will provide a handy reference for the academic researchers and students to gauge the current trend of hybrid warfare affecting Pakistani youth in its educational sector and remedial measures.

\section{QUESTIONNAIRE}

A questionnaire (as appended below) is designed to acquire the desired information about the study. Answers to these questions were collected from 22 educational institutions and prominent security managers in Pakistan. The data was gathered using survey questionnaire (using5-point Likertscaleitems) and SPSS version 19 was used to analyse the data. 


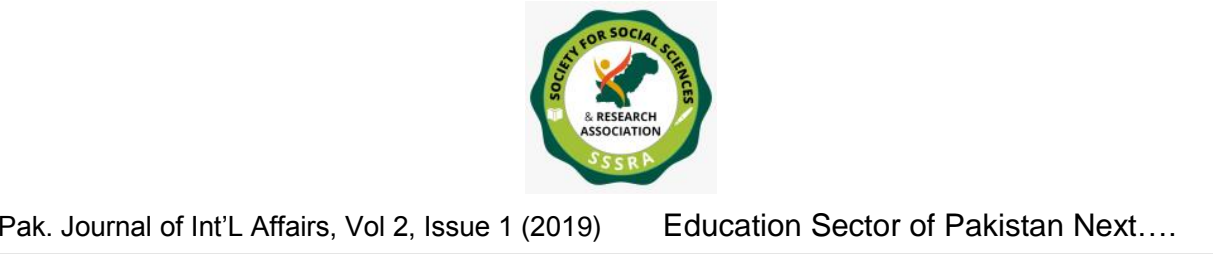

Q-1: What are the key factors that lead to violent extremism?

Q-2: What is the generalized profile of the extremists?

Q-3: What are the root causes of extremism?

Q-4: What is the role of social networking in promoting extremism in a globalized world?

Q-5: How we can respond to this threat?

\section{POSSIBLE MOTIVATING FACTORS OF EXTREMISM}

Extremism refers to advocating, engaging, preparing or otherwise supporting

"ideologically motivated or justified violence to social, economic, political and religious objectives that are rigid, uncompromising and intolerant. The world continues to confront significant threats from extremist groups resorting to violent means to advance their agenda-be it ideological, religious or political. We want our universities and colleges to be integrated communities where all staff and students are safe and where free and open debate can take place. A valued aspect of the right to freedom of expression is that individuals have the right to criticize, disagree and campaign against any issue. It can be entirely legitimate to hold a view that is radical or extreme on the political spectrum. However, it becomes unacceptable and indeed, is a criminal activity when individuals develop extremist views that lead them to promote, advocate or even undertake or facilitate violent acts.

Extremists frequently target their radicalization efforts at young people in a number of settings within the wider community and in specific institutions such as prison, youth clubs, schools, colleges and universities. The efforts of universities to foster an environment where hatred and intolerance cannot prosper will surely make it more difficult for extremists 


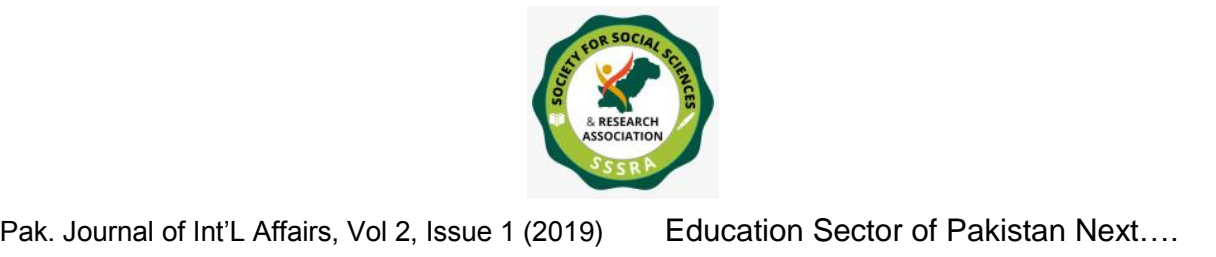

to spread their message successfully. Since the vast majority of young people pass through either Secondary or Higher Education at some point in their lives, it is absolutely critical that these institutions foster shared values. By promoting a culture of free debate, rigorous inquiry and tolerance, institutions can play their part in challenging those with extremist tendencies through rational argument.

\section{KEY FACTORS THAT LEAD TO VIOLENT EXTREMISM}

The process of an individual turning to violent extremism can occur because of a variety of factors, of which no single factor predominates. Existing evidence from this country and from overseas suggests the key factors that lead to violent extremism of this kind which include:

(a) An ideology which justifies terrorism by manipulating theology and contemporary politics.

(b) Individuals and networks who promote violent extremism through new media and in vulnerable spaces and institutions.

(c) Individuals who are vulnerable to the messaging of violent extremism for a range of personal factors.

(d) Communities which do not have resilience to resist and reject the narrative and activities of violent extremists.

(e) A number of grievances, some substantive, which resonate with individuals and are exploited by violent extremists.

\section{EXTREMISM PROFILING}

There is no single profile of those most susceptible to these factors but they are likely to be young (generally younger than 30 years) and male (although the number of women who support and participate in violent 


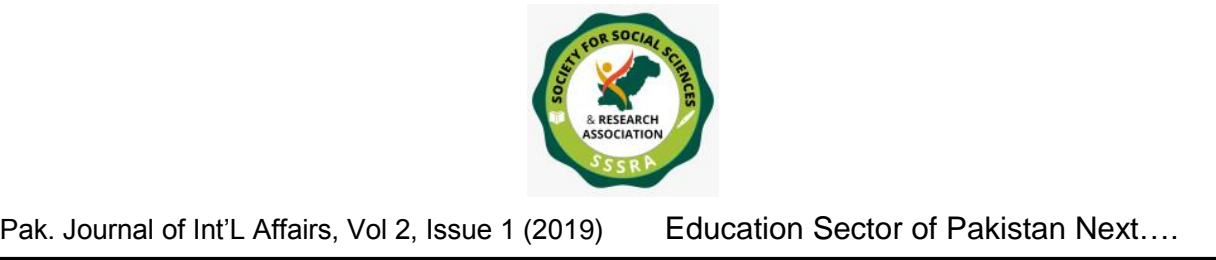

extremism is also increasing). The vast majority of Muslims in Pakistan and abroad reject both extremism and violence. Violent extremists represent only a tiny minority of individuals in Pakistan and abroad. A clear distinction should be made between these extremist individuals and the faith they might falsely claim to be associated with or represent. Extremists who wrongly argue for support for acts of terrorism present a threat to students and communities. Moreover, propagating false perceptions about the values and beliefs of Islam potentially add to a vicious circle that may fuel discrimination. This may, in turn, exacerbate violent extremism in the name of faith, as individuals perceive that they are increasingly marginalized.

\section{ROOT CAUSES OF EXTREMISM}

The following factors of extremism belong to this family of root causes: -

(a) State and governance failure. Legitimate states exercise functional

sovereignty in their domestic polity, and establish the institutional architecture required to provide durable platforms for collective deliberation and participation in political processes. The state ensures access to and distribution of social, economic and political resources; and establish overarching conditions for peace and stability. However, when states begin defaulting on performing these basic functions, inequalities in resource ownership and distribution take roots, which then create power disparities. Failure to deliver basic public services creates a vacuum that is occupied by violent extremist groups that begin offering and providing public goods, welfare services, and alternatives, especially for the most marginalized segments of a polity. Failures or inefficiencies in the justice dispensation mechanisms erodes trust in the state, and allows violent extremist groups to setup alternative options for dispensing justice; often through violence and miscarriages of justice principles. Similarly, the inability of a state to provide security and establish law and order creates the physical space for violent extremist groups to operate freely, impose 


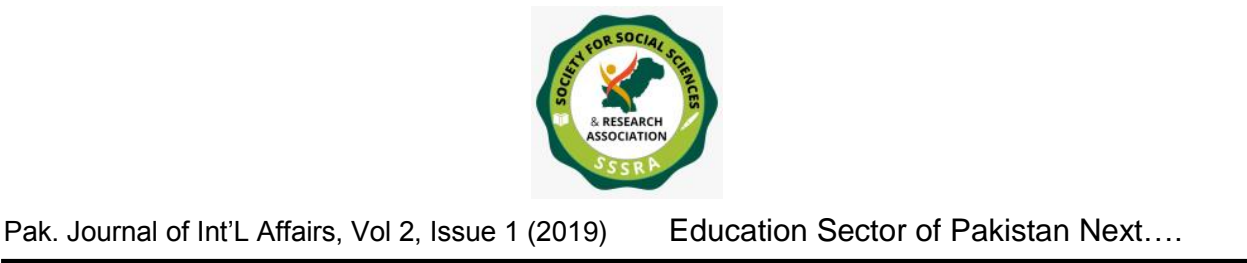

their own order, and incentivize individuals to join such groups as the most effective and powerful actors, with a competing monopoly over violence. Where states use groups with violent extremism as proxies against domestic and foreign adversaries, security and development challenges from violent extremism can quickly become uncontrollable.

(b) State Repression and Human Rights. Direct or indirect violation of

human rights and basic human dignity by the state, or non-state actors mimicking this behavior, creates victims with legitimate grievances. These grievances can quickly morph into a desire for revenge, which is provided real and meaningful outlets by violent extremist groups.

(c) Endemic Conflict and Insecurity. Conflicts destabilize states and lead to all symptoms of classic state failure. Moreover, prevalent insecurity and violence allows for easy access to violence and the resources required to inflict damage to life and property. In such contexts, violent extremist groups find substantial space to participate in, complicate and perpetuate conflicts.

(d) Entrenched Corruption and Elite Impunity. Entrenched patterns of individual and institutional corruption, coupled with impunity and lack of accountability, can provide violent extremist groups with two opportunities to find a foothold. First, widespread corruption and lack of accountability and transparency allows violent extremists to spin

narratives against the state and its institutions, and frame themselves and their objectives as the legitimate alternatives to the 'immorality' of the state and elite. Second, systemic corruption allows opportunities for violent extremist groups to build alliances and linkages with criminal and illegal networks and gangs to find operational space and resources. 


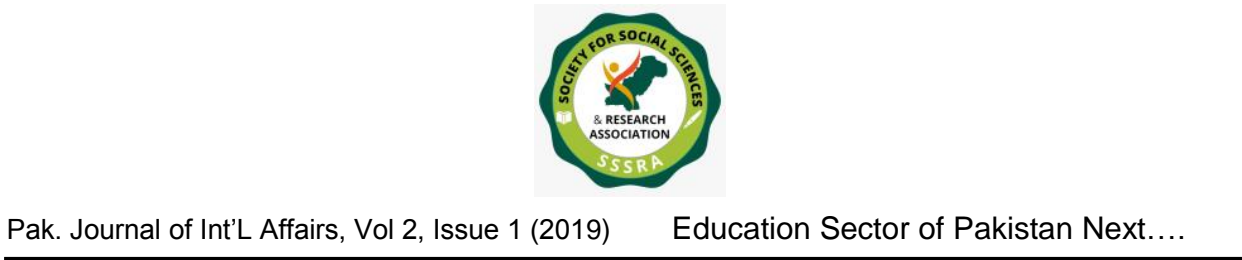

(e) Social Marginalization and Fragmentation. Dislocation and exclusion in

the form of social marginalization and fragmented identities can become powerful structural forces for driving and sustaining violent extremist narratives and groups. When the state and cultural institutions fail to build inclusive opportunities for participation and a sense of belonging to a polity, they render individuals susceptible to manipulation, radicalization and recruitment into violent extremist groups.

(f) Cultural Threat Narratives. This driver of violent extremism is quite prominent in the public posturing, messaging and recruitment narratives disseminated by extremist groups. For example, narratives of existential threats of domination can create a sense of impending crisis, injustices and oppression. Violent extremist groups utilize this driver at the local and global levels. For example, minorities, secular groups, media etc can be painted as seeking to dominate, monopolize and transform religious identities and freedoms. Globally, international actors and foreign countries can be presented as oppressive enemies that need to be confronted through violence and conflict. These narratives combine to provide violent extremist groups with legitimacy.

(g) Low Literacy Levels. Low levels of educational attainment can lead to the proliferation of violent extremist groups. Current evidence for this hypothesized factor is weak. However, when the global spread of violent extremist groups is taken into account, countries with low literacy levels are often the main theaters of recruitment and

operations for such groups and networks. (Sukarieh, 2018) Violent extremism thrives on framing and disseminating favorable narratives. Without knowledge and information, and particularly in the absence of quality education, it is highly likely that individuals become susceptible 


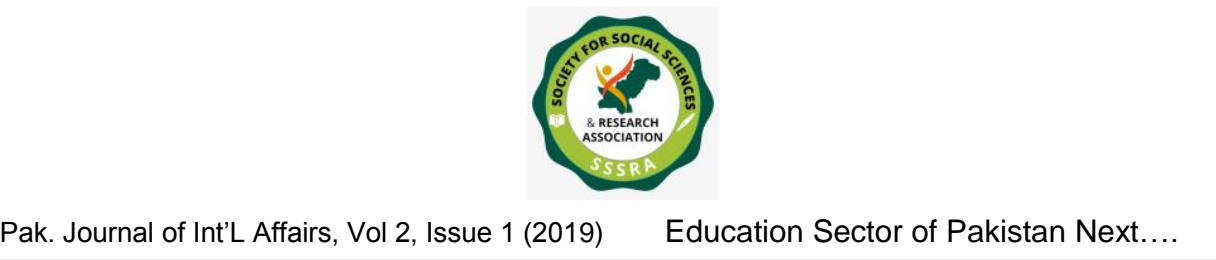

to becoming foot soldiers in these groups. Conversely, the emergence of homegrown terrorism and extremism in Europe shows that operatives often have basic to advanced levels of educational attainment. This development militates against identifying educational deficiency as a driver of violent extremism. However, and critically, evidence from Pakistan on this hypothesized driver is mixed. Groups like TTP are often led and manned by individuals with negligible to absent educational qualifications and no formal education credentials. Conversely, recent evidence shows that leaders and recruits into new violent extremist groups, especially in urban Pakistan are often university-educated, and are recruited at their universities and colleges. Educational and sociopsychological theories suggest that when educational curriculum becomes narrow, intolerant, and inimical to out-groups (minorities or external actors), a general consciousness of aggression, hatred and rejection beds roots. This driver of violent extremism needs to be carefully deconstructed by reforming the structure and content of curriculum taught in Pakistan.

(h) Poverty and Unemployment. Overarching and cross-country data indicates that violent extremist groups thrive, operate and inflict the greatest damage in countries with high levels of poverty, low incomes, and wide spread unemployment. Global evidence on the role of poverty as a contributing factor in the rise of violent extremism is mixed at best. (Apergis, 2018)

However, evidence from the country suggests that poor Pakistanis, especially the urban poor, exhibit negative attitudes towards violent militant and extremist groups operating in the country; particularly in comparison with middle-class citizens that report comparatively lower levels of antipathy towards such groups. Poor and economically weak states are vulnerable to violent extremism, terrorism and militancy. Poverty, unemployment and wide income and wealth differentials point to systemic deficiencies and inequalities in a state's economic structure

(i) Dislocation and Identity Crisis. Across the world, in different cultural contexts, ruptures in identities, and weakening of a sense of 


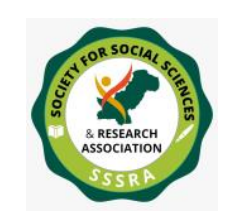

Pak. Journal of Int'L Affairs, Vol 2, Issue 1 (2019)

Education Sector of Pakistan Next....

belonging act together to create feeling of disconnection, disenchantment, and dislocation for individuals. In such circumstances, social and cultural institutions fail to provide adequate and healthy socialization experiences to individuals. This then translates into disjuncture between individuals, their communities and the collective cultural experiences and identities. (Gulmez, 2018) Migrants and immigrant communities offer particularly vivid illustrations of instances where states and their institutions fail to provide smooth socialization and integration experiences. When such conditions combine, they render alienated individuals highly susceptible and vulnerable to becoming radicalized, and joining violent extremist groups.

(j) Sense of Belongingness, Risk-taking, Adventure and Personal Empowerment.

An associated outcome of the aforementioned social exclusion, up rootedness, and identity crisis is that such individuals, and particularly youth, seek out peer networks that allow them to cultivate a sense of belonging, and provide a convenient narrative decrying the prevailing social, cultural, economic and political systems. (Frosh, 1991) Politically and economically disengaged young men and women are particularly receptive to the competing alternatives offered by violent extremist groups. When these conditions combine, individuals tend to join violent extremist groups to integrate themselves into groups and activities that seemingly allow risk-taking adventures by challenging and undermining security and development in a society. In the same manner, joining militant groups offers marginalized and alienated individuals with a sense of personal empowerment by temporarily boosting their self-esteem and giving them access to tools that appear to orchestrate change in their communities.

(k) Access to Material Resources. In many instances, joining militant networks and extremist groups offer direct and ready access to material resources that are otherwise absent in the life of a recruit. Money and material comforts are one facet of this incentive. Access to weapons, vehicles and freedom of mobility fulfills the individual's need to access material resources that offer cultural and social status. 


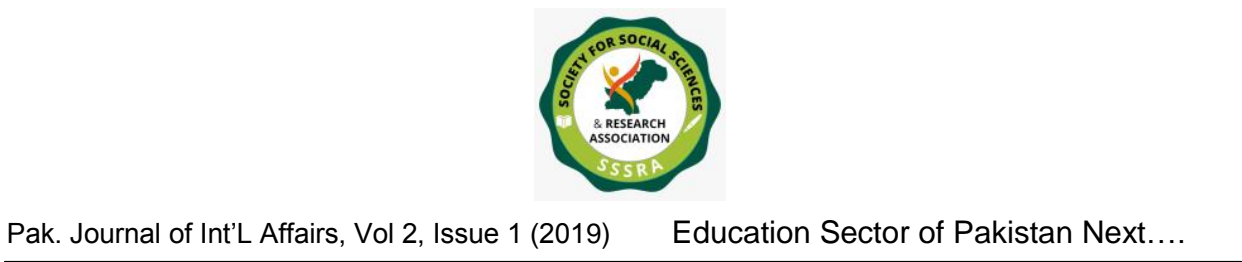

(1) Opportunity to Earn Social Capital, Personal Glory and Fame. Joining violent extremist groups, especially in societies where such groups have freedom of mobility and operations, provides members with social status; and the mobility that is otherwise unavailable and inaccessible for them. Moreover, for many individuals with severe identity crisis and psychological distress, joining and participating in violent extremist groups, offers personal glory and fame.

\section{ROLE OF SOCIAL NETWORKS IN PROMOTING EXTREMISM IN A GLOBALIZED ENVIRONMENT}

Violent extremist groups sustain their recruitment channels through personalized interactions and individual influences. They consider individuals, particularly youth with identity crisis, experiences of sustained discrimination and marginalization, and a perceived sense of injustice, who are exposed to relatives, friends, and neighbors who are already sympathizers of violent extremist groups. In this frequently recurring and recorded situation, disgruntled and dissatisfied individuals are manipulated by members (often charismatic leaders or other members who are a part of the radicalized individual's social network) of violent extremist groups. Readily tailored narratives are offered to nurse perceived grievances and material, spiritual and socio-cultural rewards are offered as incentives to join the group. (Adomson, 2005)

Narratives, Literature and Discourse. Violent extremist groups manufacture and offer convenient narratives that challenge and identify an existential enemy, manufacture perceived grievances and a sense of oppression and injustice, and seek to use violence as a revenge tactic. Conspiracy theories regarding domestic and foreign actors, seen as enemies, soften the public opinion and sympathy for violent extremist groups. Complicating this landscape is the communicative strategy of contemporary violent groups like Daesh. These groups have actively embraced new media technologies and easily reach out to individuals with the aforementioned challenges across cultural and national boundaries. 


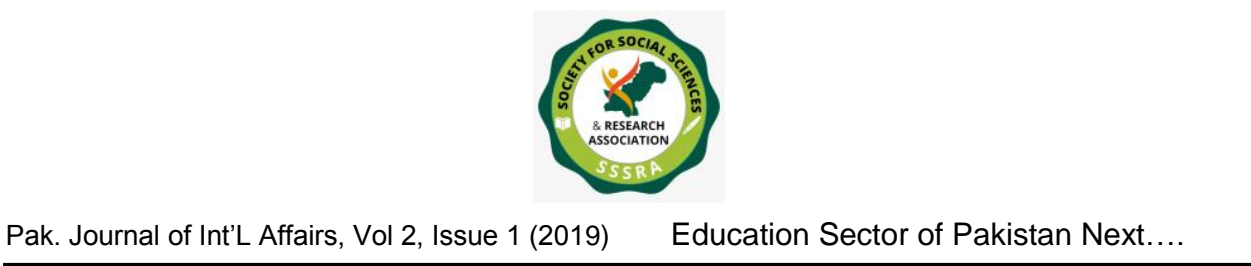

\section{RESPONSIBLE SOCIETAL RESPONSE TO EXTREMISM}

\section{MINDSET OF EXTREMISM}

Extremism is a mindset where only a single truth is considered to be valid. (Stankov, 2010) It is the antithesis of liberalism. But Pakistani education explicitly rejects liberal objectives. Some variations exist across rich and poor schools, between villages and cities, and across provinces. However, the basic road-map is provided by the school curriculum, textbooks, teachers, and examinations. Education is the carrier of liberal values, it is the natural enemy of extremism because it enriches and broadens the mind, enables one to entertain a thought without necessarily accepting it, and creates willingness to live in a society that is democratic, pluralistic, and diverse. (Ball, 1997) But unfortunately, our education system is historically person specific and could not evolve to serve the purpose. Even if the heroes of the Pakistan Movement, Jinnah, Iqbal, Sir Syed Ahmed Khan-were not actually orthodox Muslims, they were to be shown as such.

\section{A PSYCHOLOGICAL WARFARE}

It's also important to understand that terrorism is psychological warfare. Terrorism is an effort to reach political objectives by inspiring fear, perpetrated by people aiming to compensate for a lack of military power. If there is no emotional response, terrorism cannot achieve its desired outcomes. That puts governments in a tricky position: balancing the public's need for information with the very real possibility of reinforcing terrorists' goals of spreading fear. To respond effectively to threats, governments and individuals need to reduce both terrorists' ability to attack and their motivation. Yet most fail to understand the motivation component. When ISIS beheads a journalist in Syria or Boko Haram kidnaps schoolgirls in Nigeria or TTP attacks a schools or mosque in Pakistan, people can be tempted to explain the terrorists' actions as "evil," but that oversimplifies the situation. 


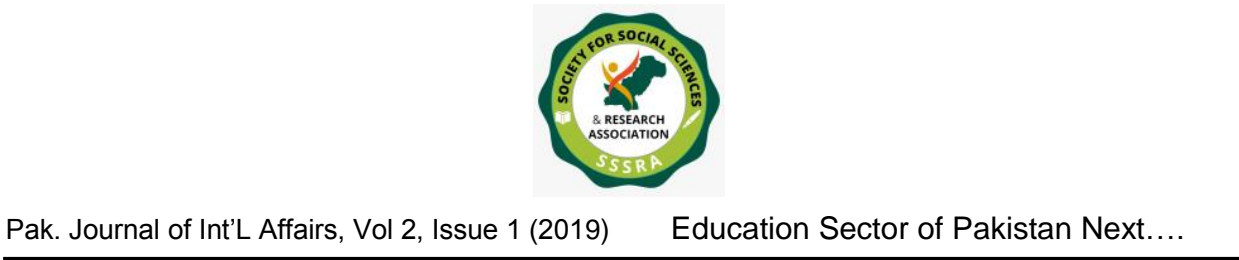

\section{Terrorists Mindset}

Terrorists have to believe two things to engage in violence: (Pfundmair, 2018) Terrorism is justified. Terrorists believe that they have a worthwhile cause that cannot be achieved through other means. Of course, not everyone with the same political goal becomes a terrorist. Research shows that one factor that spurs potential terrorists to violence is a quest for personal significance, or a desire to feel more valued and important. Another is a desire to attain higher social status when more conventional routes to power and respect are inaccessible.

Terrorism is effective. Terrorists believe that violence will inspire enough fear to make people and governments take some sort of action. That action might be toward the terrorists' political goals or it might be a military response that the terrorists can use to further justify their political Results of National Action Plan (Achievements) (NACTA, 2018)

Following are the claimed achievements of NACTA :

- Timely communication of around 4000 threat alerts and more than 1650 information reports have been exercised in the past 20 months.

- $\quad$ Quick operationalization of Fair Trial Act and ATA (Amendment) Act throughout the country

- Monthly reviews/analyses of terrorist incidents across the country

- Revival of Pakistan Automated Fingerprint Identification System (PAFIS) to maintain a country-wide fingerprint database for detection of criminals, and enhance the capacity of Cybercrime wing and Intellectual Property Rights wing of FIA

- Induction of intelligence software (i2) for assistance in investigation / backtrack in 


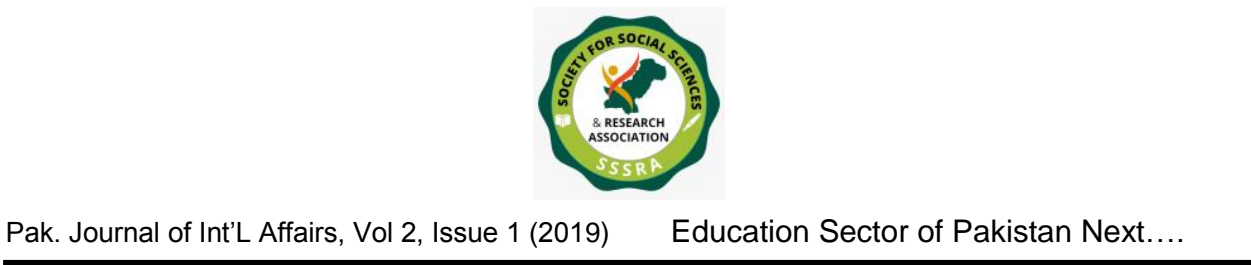

FIA.

- $\quad$ NACTA has prepared a draft model law for NGOs/NPOs for their effective registration, regulation, audit and enforcement of penal provisions in case of violations with the ultimate aim to protect their misuse for terrorist financing

- $\quad$ NACTA has taken the lead role in regulating movement of cash across land and other routes in collaboration with stakeholders like Federal Board of Revenue, State Bank of Pakistan, Anti-Narcotics Force, Federal Investigation Agency \& Intelligence Agencies to effectively combat money laundering and terrorist financing.

- $\quad$ FIA's centralized Integrated Border Management System (IBMS) link is being provided to Customs department for effective profiling of passengers and targeted search \& seizure of contraband items and illegitimate currency

- $\quad$ FIA (IBMS) has also provided a link to NACTA enabling it to monitor activities of person on Schedule IV of ATA, 1997.

- $\quad$ NACTA has put in a lot of effort for stringent controls on Branchless Banking with the aim of making this money-transfer system fully protected against misuse for terrorist financing.

- $\quad$ Sixty-six, 66 Organizations / Splinter Outfits have been notified as Proscribed by Ministry of Interior u/section 11-B-(1) r/w Schedule-I, AntiTerrorism Act, 1997

- $\quad$ Four 4 Organizations have been put under watch by Ministry of Interior u/section 11-D-(1) r/w Schedule-II, Anti-Terrorism Act, 1997.

IDEOLOGICAL SECURITY 


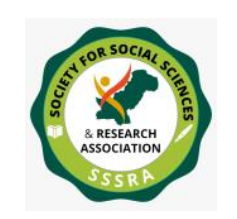

Pak. Journal of Int'L Affairs, Vol 2, Issue 1 (2019)

Education Sector of Pakistan Next....

As per common belief, extremism and terrorism stem from the cradle of ignorance, poverty and unemployment. (Hudson, 2018) The people involved in terrorism are thought to be students of traditional religious seminaries deprived of modern education. They perpetrate violent acts, indoctrinate and recruit underage radicalized youth through concocted stories and misinterpretation of religion.

The Afghan Jihad against the Soviets in the 80s and 90s has radicalized Pakistani society and the education system of Pakistan is no exception in this regard. Intolerance and extremism have affected both religious seminaries as well as modern educational institutions. Resultantly, the terrorists have succeeded in using our highly educated youth for their heinous crimes. Currently, Pakistan is fighting the lot of highly educated terrorists equipped with modern technology to fool the law enforcement agencies. Ansar-ul-Sharia Pakistan - a recently emerged terrorist group of highly educated youth of Pakistan inspired by Al-Qaeda and Osama Bin Laden is a splinter group from the so-called Islamic State (IS) with members previously part of IS, TTP, Al-Qaeda and Lashkar-e-Jhangvi. The group formed as the members returned back Pakistan after the defeat of the IS in Iraq and Syria. Such groups may have many more battlehardened militants that could use such small splinter groups to carry out major attacks in Pakistan. With the defeat of the IS in Syria and Iraq the influx of militants to Pakistan could continue that could further complicate the situation. There needs to promote ideological security on the part of Pakistan to deal with the emerging situation. Pakistan also needs to fight extremism and terrorism on military, political as well as social front. (Federico, 2018) Otherwise, the enemy can ruin our youth with its toxic ideology of terror and tyranny.

It is not the right approach to think socio-economic factors as the only root cause of extremism and terrorism to deal with the menace of terrorism and extremism. It has much to do with the extremist's narrative based on certain religious and political beliefs. People recruited by the Ansar-ulSharia Pakistan are highly educated and usually belong to well-off families which indicate at the target groups of extremists. Fighting extremism is to fight the extremist narrative. But the question is, as a state, what narrative 


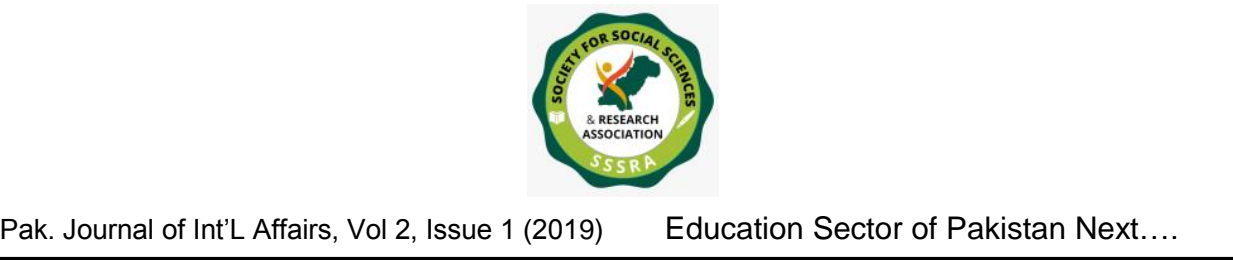

does Pakistan have and what is being done to propagate it? It has now been clearly discovered that potential militants excessively use social media and other software applications for communication and propaganda purposes which indicates that the terrorists are using the alternative communication media since traditional means of communications are being constantly monitored by law enforcement agencies. Social media and communication softwares are being excessively used all over the world by the militants to indoctrinate and recruit people for their heinous designs. Noreen Leghari case can be quoted as the prime example of such indoctrination through social media. (Orakzai, 2018)

\section{THE WAY FORWARD}

In order to eradicate the menace of extremism and terrorism from the country, Pakistan will have to devise an effective monitoring mechanism of religious seminaries, colleges and universities as the terrorists have succeeded to penetrate our educational institutions. Co-curricular activities and peaceful student politics could allow the youth to use their energies in a positive direction; therefore, ban on student unions must be lifted with immediate effect. The reality is that the drivers of violent extremism vary within as well as between countries, and over time. Local communities are best placed to understand what these drivers are, why they change, and how best to address them. And yet all too often they are excluded from academic research and policy dialogue on countering violent extremism.

The first step to engaging communities is to identify them. Development actors normally focus on the poorest communities; security actors on those already infected by extremism. But the real focus for efforts to counter violent extremism should be those communities most at risk of succumbing to violent extremism. These may be neither the poorest communities, nor those in regions already afflicted.

A second step is to seek out appropriate interlocutors within these communities. These may be school teachers, religious leaders or sports coaches. Legitimacy may or may not be associated with elected office. 


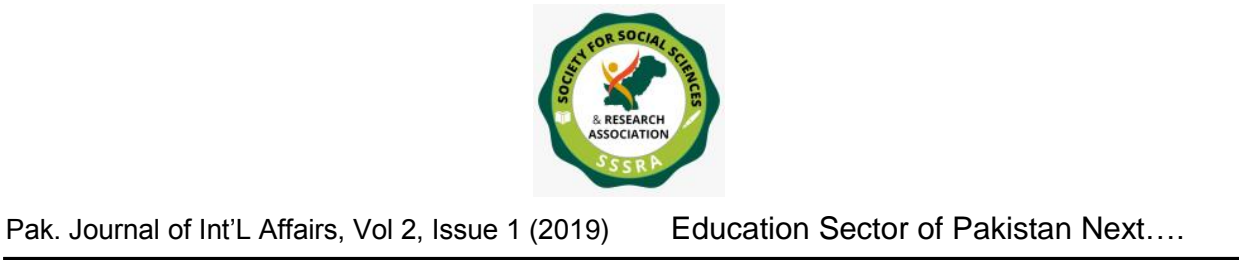

Often the most significant partners are the quietest- empowering young people and women is important.

A third step is to try to build confidence. Sustainable and replicable efforts to counter radicalization at the local level will not be achieved unless there is trust between different communities, between communities and the local and national government, and between all these actors and the international community. The legacy of the "war on terror" is a severe trust deficit.

A fourth step is to unlock the potential of local communities to develop tailored, local responses to the threat of violent extremism. But in many countries there is a significant funding gap. These communities may not be obvious development or security priorities; they may lack the skills or networks to raise money; or the political credibility to be allowed to do so.

A fifth step is to expand local successes. Providing support to specific local initiatives may achieve local results (although demonstrating impact is a challenge), but risk being a drop in the ocean when compared to national and transnational drivers of violent extremism. All these steps to engaging local communities need to be systematized so that they can be applied elsewhere, both nationally and internationally, and success stories need to be broadcast widely, while failures should be acknowledged and understood.

\section{CONCLUSION}

Comprehensive security policies that promote stability and the human development of all people through implementing socially fair, organizationally sustainable and economically responsible policies in all subsectors are necessary to achieve such fair long-term development. Media management, intelligence, Improvisation and technological development are the essence of development in security domain. Nobody can predict when next war will start and what would be the nature of that war but the time we are passing by we are in constant state of hybrid war, where our enemies are intelligently blending conventional and non- 
conventional techniques to achieve her policy objectives. Only comprehensive security response can avert such moves. Our most precious asset is our youth and we must pay our full attention and focus to save it from extremism. Educational institutes are the backbone of societal development and it would be the worst-case scenario if these might polluted with extremist ideologies". However, I am sure as we have got successes in previous security operations, this time again Insha'Allah we again defeat our enemies in her new design and scheme of extremism. 


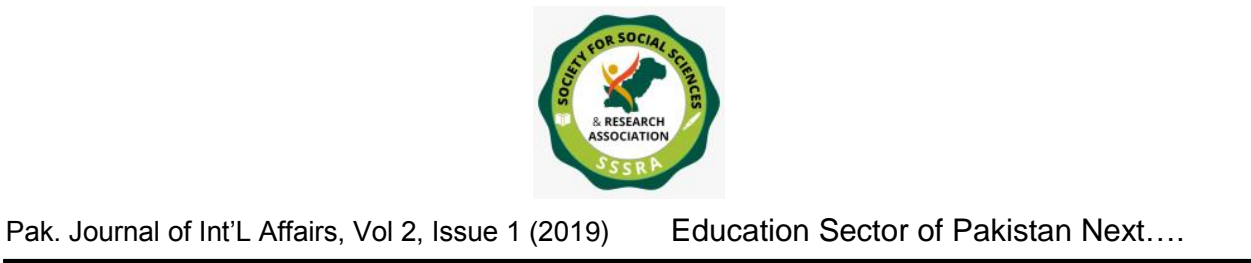

\section{REFERENCES}

Adamson 1, F. B. (2005) Globalisation, transnational political mobilisation, and networks of violence. Cambridge Review of International Affairs, 18(1), 31-49.

Ahmar, M. (2001). The Challenges of the Conflict Resolution and Security in 21st Century: Problems and Prospects. Karachi: University of Karachi.

Apergis, N \& Marina-S. K. (2018). Poverty and the resource curse: Evidence from a global panel of countries. Research in Economics 72(2), 211-23.

Butt, U. (2010). Pakistan's Quagmire Security, Strategy, and the Future of the Islamic-nuclear Nation. New York: Continuum.

Ball, S. J. (1997). Markets, equity and values in education. In Pring R. \& Walford, G. (Eds.), Affirming the comprehensive ideal. London: The Falmer Press.

Cavelty, M. D. \& Mauer V. (2010). The Routledge Handbook of Security Studies. Milton Park, Abingdon, Oxon: Routledge.

Chayes, S. (2015). Thieves of State: Why Corruption Threatens Global Security, Washington DC: Norton \& Company.

Federico, C. \& Malka. A. (2018). "The contingent, contextual nature of the relationship between needs for security and certainty and political preferences: Evidence and implications, Political Psychology 39(3), 3-48.

Gulmez, D. B. (2018). Crisis and Crimean Tatars: Discourses of Selfdetermination in flux. In Crisis and Change in Resende E., Gulmez, D. B. \& Budryte D.(Eds.), Post-Cold War Global Politics, (pp. 203-224). Cham: Palgrave Macmillan. 


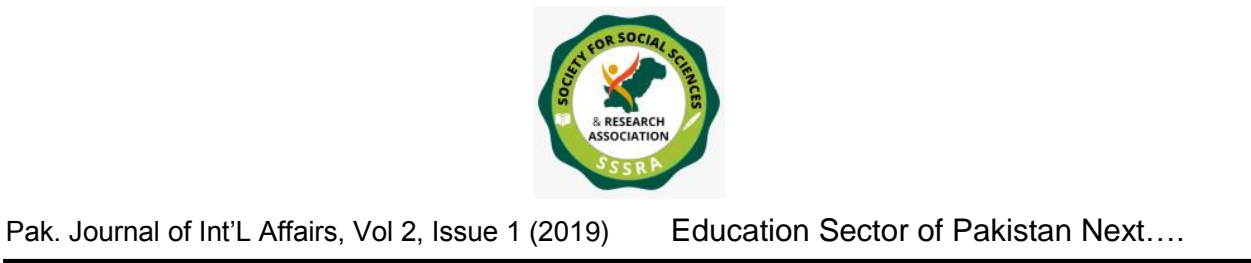

Hudson, R. A. (2018). Who Becomes a Terrorist and Why? The Psychology and Sociology of Terrorism. New York, NY: Skyhorse Publishing Inc.

Lodhi, M. (Ed.). (2011). Pakistan: Beyond the "crisis State" . New York: Columbia University Press.

Markey, D. S. (2013). No Exit from Pakistan: America's Tortured Relationship with Islamabad. New York , NY: Cambridge University Press.

National Counter Terrorism Authority (NACTA). (2018). Government of Pakistan, Retrieved from http://www.nacta.gov.pk.

Orakzai, S. B. (2018). Pakistan's Approach to Countering Violent Extremism (CVE): Reframing the Policy Framework for Peacebuilding and Development Strategies. Studies in Conflict \& Terrorism.

Pfundmair, M. (2018). Ostracism promotes a terroristic mindset. Behavioral Sciences of Terrorism and Political Aggression. Rtrieved from https://www.tandfonline.com/doi/abs/10.1080/19434472.2018.1443965.

Stankov, L., Saucier, G. \& Knežević. G. (2010). Militant extremist mindset: Proviolence, Vile World, and Divine Power. Psychological assessment 22(1), 70-86.

Stephen. F. (1991). Identity crisis: Modernity, psychoanalysis and the self. New York, NY: Palgrave Macmillan.

Sukarieh, M. \& Tannock. S. (2018).The global securitisation of youth. Third World Quarterly 39(5), 854-70. 